\title{
THE EFFECT OF KNOWLEDGE ON VOTING INTEREST PRODUCTS PT. MANDIRI SHARIA BANK PADANGSIDIMPUAN (Case Study to Guru Al-Azhar Bi'ibadillah Ujung Gading District Angkola stem)
}

\author{
Elna Sriwanna ${ }^{1}$, Ikhwanuddin Harahap ${ }^{2}$, Windari ${ }^{3}$, Ali Hardana ${ }^{4}$ \\ ${ }^{1}$ IAIN Padangsidimpuan (Perbankan Syariah, FEBI, IAIN Padangsidimpuan) \\ ${ }^{2}$ IAIN Padangsidimpuan (Hukum Syariah, FEBI, IAIN Padangsidimpuan) \\ ${ }^{3}$ IAIN Padangsidimpuan (Perbankan Syariah, FEBI, IAIN Padangsidimpuan) \\ ${ }^{4}$ IAIN Padangsidimpuan (Perbankan Syariah, FEBI, IAIN Padangsidimpuan) \\ Elnasriwanna@gmail.com ${ }^{1}, \underline{\text { ikhwanuddinharahap@iain-padangsidimpuan.ac.id }{ }^{2}}$, wwindariok@gmail.com ${ }^{3}$ \\ alihardana@iain-padangsidimpuan.ac.id $^{4}$
}

\begin{abstract}
ABSTRAK
Penelitian ini dilatarbelakangi adanya anggapan sebagian guru Al azhar Bi'ibadillah yang mengatakan bahwa bank syariah dan bank konvensional tidak ada terdapat perbedaan. Disamping itu sosialisasi yang dilakukan oleh Bank Syariah khususnya PT Bank Syariah masih rendah. Rumusan masalah pada penelitian ini yaitu apakah terdapat pengaruh pengetahuan terhadap minat memilih produk PT Bank Syariah Mandiri Padangsidimpuan pada guru Al azhar Bi'ibadillah Ujung Gading Kecamatan Batang Angkola. Penelitian ini bertujuan untuk mengetahui pengaruh pengetahuan terhadap minat memilih produk PT Bank Syariah Mandiri Padangsidimpuan pada Guru Al Azhar Bi'ibadillah Ujung Gading Kecamatan Batang Angkola. Kegunaan penelitian ini untuk menambah wawasan bagi peneliti dan memberikan informasi serta pengetahuan tentang perbankan syariah bagi guru Al azhar Bi'ibadillah.Penelitian ini adalah bersifat kuantitatif dengan regresi linear sederhana, pengambilan sampel menggunakan teknik sensus disebut juga teknik sampling jenuh, dengan jumlah populasi 49 dan sampel 49, dengan menggunakan bantuan program SPSS Versi 22. Berdasarkan hasil penelitian uji koefisien determinasi (R2) dapat diketahui bahwa nilai R Square sebesar 0,121 artinya variabel pengetahuan mampu menjelaskan variabel minat sebesar $12 \%$ sedangkan $88 \%$ sisanya dijelaskan oleh variabel lain yang tidak dimasukkan dalam model ini. Dalam arti lain bahwa masih ada variabel yang mempengaruhi minat memilih produk PT bank syariah mandiri padangsidimpuan selain pengetahuan. Berdasarkan hasil penelitian ini menunjukkan berpengaruh yaitu pengetahuan terhadap minat dengan nilai ttabel $>$ thitung $(2,544>2,012)$.

Kata Kunci: Pengetahuan, Minat
\end{abstract}

\begin{abstract}
This research is motivated by the assumption that some Al Azhar Bi'ibadillah teachers say that there are no differences between Islamic banks and conventional banks. Besides that, the socialization carried out by Islamic Banks, especially PT Bank Syariah, is still low. The formulation of the problem in this study is whether there is an influence of knowledge on the interest in choosing PT Bank Syariah Mandiri Padangsidimpuan products on the teacher of AlAzhar Bi'ibadillah Ujung Gading, Batang Angkola District. This study aims to determine the effect of knowledge on the interest in choosing PT Bank Syariah Mandiri products in
\end{abstract}


Padangsidimpuan in Al-Azhar Bi'ibadillah Ujung Gading Teachers, Batang Angkola District. The purpose of this research is to add insight to researchers and provide information and knowledge about Islamic banking for Al Azhar Bi'ibadillah teachers. This research is quantitative with a simple linear regression, sampling using census techniques also called saturated sampling techniques, with a population of 49 and 49 samples, using the help of SPSS Version 22 program. Based on the results of the test of the coefficient of determination (R2) it can be seen that the R Square value of 0.121 means that the knowledge variable is able to explain the variable of interest by $12 \%$ while the remaining $88 \%$ is explained by other variables not included in this model. In another sense that there are still variables that affect the interest in choosing PT Syariah Syariah Mandiri products in addition to knowledge. Based on the results of this study indicate the influence of knowledge of interest with the value of tthitung $(2.544>2.012)$.

Keywords: Knowledge, Interest

\section{A. PENDAHULUAN}

Perbankan merupakan lembaga
keuangan yang memiliki fungsi utamanya
adalah untuk menghimpun dana masyarakat
dan menyalurkannya. Adanya perbankan
memberikan kemudahan bagi masyarakat
untuk bertransaksi menggunakan jasa
perbankan. Di Indonesia ada dua sistem perbankan yaitu perbankan syariah dan perbankan konvensional. Perbankan syariah adalah segala sesuatu yang menyangkut tentang bank syariah dan Unit Usaha Syariah (UUS), yang mencangkup kelembagaan, kegiatan usaha, serta cara dan proses dalam melaksanakan kegiatan usahanya. Bank syariah memiliki fungsi menghimpun dana dari masyarakat dalam bentuk titipan dan investasi dari pihak pemilik dana. Fungsi lainnya ialah menyalurkan dana kepada pihak lain yang membutuhkan dana dalam bentuk jual beli maupun kerja sama usaha. (Ismail, 2014,hal.25-
Bank syariah pada dasarnya adalah entitas yang melakukan penghimpunan dana dari masyarakat dalam bentuk pembiayaan atau dengan kata lain melaksanakan fungsi intermediasi keuangan. Berdasarkan UU No. 21 tahun 2008 tentang Perbankan Syariah, Bank Syariah adalah bank yang menjalankan kegiatan usaha berdasarkan prinsip syariah, atau prinsip hukum Islam yang diatur dalam fatwa Majelis Ulama Indonesia seperti prinsip keadilan, dan keseimbangan ('adlwatawazun), kemaslahatan (maslahah), universalisme (alamiyah), serta tidak mengandung gharar, maysir, riba, zalim dan obyek yang haram.

Kehadiran bank yang berdasarkan syariah di Indonesia masih relatif baru yaitu pada awal tahun 1990-an, meskipun masyarakat Indonesia merupakan masyarakat muslim terbesar di dunia. Prakarsa untuk mendirikan bank syariah di Indonesia dilakukan oleh Majelis Ulama Indonesia (MUI) pada tanggal 18-20 Agustus 1990. Namun, diskusi tentang bank syariah sebagai basis ekonomi 
Islam sudah mulai dilakukan pada awal tahun 1980 (Kasmir, 2009, hal. 187)

Salah satu anggapan tentang bank syariah yang beredar di sebagian masyarakat saat ini adalah bahwa bank syariah tidak ada bedanya dengan bank konvensional. Selain itu, dari aspek eksternal, sektor perbankan syariah memiliki tantangan dari sisi pemahaman sebagian masyarakat dan Guru Al-Azhar Bi'ibadillah yang masih rendah terhadap pengetahuan operasional bank syariah (PT Bank Syariah Mandiri).Pengetahuan guru Al-zhar Bi'ibadillahmengenai perbankan syariah juga merupakan salah satu faktor yang mempengaruhi minat guru Al azhar Bi'ibadillahuntuk menjadi nasabah bank.MenurutZakiah Daratjat "minat merupakan suatu kecenderungan jiwa yang tetap ke jurusan sesuatu hal yang berharga bagi orang lain". (Zakiah Dratjat, 1995, hal. 133)

Menurut teori Holland, sebagaimana dikutip oleh Djaali menyatakan bahwa, "minat adalah kecenderungan hati yang tinggi terhadap sesuatu. Minat tidak timbul sendirian, ada unsur kebutuhan, misalnya minat belajar, dan lain-lain". Dari definisi diatas dapat disimpulkan bahwa minat merupakan keinginan untuk memiliki sesuatu dan tanpa ada paksaan dari orang lain. (Djaali, 2007, hal. 122)

Menurut Abdul Rahman Shaleh dan Muhbib Abdul Wahab, minat adalah kecenderungan untuk memberikan perhatian dan bertindak terhadap orang, aktivitas atau situasi yang menjadi objek dari minat tersebut dengan disertai perasaan senang. Berdasarkan definisi diatas terkandung suatu pengertian bahwa minat itu ada pemusatan perhatian subjek, ada usaha untuk mendekati, memiliki, mengetahui dari subjek yang dilakukan dengan perasaan senang. (Abdul Rahman Saleh dan Muhbib Abdul Wahab, 2004, hal. 263-264).

Ada beberapa faktor yang mempengaruhi timbulnya minat, dan secara garis besar dapat dikelompokkan menjadi dua yaitu yang bersumber dari dalam diri individu yang bersangkutan (misalnya, bobot, umur, jenis kelamin, pengalaman perasaan mampu, kepribadian), dan yang berasal dari luar mencakup lingkungan keluarga, lingkungan sekolah dan lingkungan masyarakat. Faktor lingkungan justru mempunyai pengaruh lebih besar terhadap timbul dan berkembangnya minat seseorang. Disamping itu juga karena objek dari minat itu sendiri sangat banyak sekali macamnya, yaitu dorongan dari dalam diri individu, motif sosial, faktor emosional.

\section{B. METODE}

Penelitian ini akan dilakukan di Ma'had Al-Azhar Bi'ibadillah Desa Tahalak Ujung Gading, Kecamatan Batang Angkola, Kabupaten Tapanuli Selatan, Sumatera Utara. 22773. Penelitian ini dilakukan sejak bulan Mei 2019 sampai Februari 2020.

Jenis penelitian ini adalah penelitian kuantitatif analisis deskriptif. Penelitian deskriptif adalah penelitian yang berusaha menjelaskan suatu gejala, peristiwa, kejadian yang terjadi sekarang. Instrumen adalah alat 
yang digunakan untuk pengumpulan data, jadi semua alat yang bisa mendukung penelitian untuk mendapatkan hasil serupa data disebut instrumen. Adapun sebagai berikut:

1. Angket

Yaitu daftar pertanyaan yang
disusun secara sistematis yang
diberikan kepada orang yang
bersangkutan dengan maksud agar
orang yang diberi angket itu bersedia
memberikan respon sesuai dengan
permintaan pengguna. Dalam hal ini
peneliti menggunakan angket tertutup
dimana pertanyaan yang dibuat
sedemikian rupa, sehingga responden
dibatasi dalam memberi jawaban
kepada beberapa alternatif saja
ataupun kepada satu jawaban saja.
Kemudian angket yang digunakan
sebagai instrument dalam penelitian
ini menggunakan skala Ordinal
merupakan skala pengukuran yang
digunakan untuk menbedakan data.
Sekaligus mengandung unsure
pemeringkatan (ranking), derajat
(degree), atau tingkatan (level) melalui
penilaian tertentu.

2. Observasi atau pengamatan

Yaitu kegiatan keseharian manusia dengan menggunakan panca indera mata sebagai alat bantu utamanya.

3. Dokumentasi
POINT Vol. 1, No. 1, Jul 2020 Sejumlah besar fakta data tersimpan dalam bahan yang berbentuk dokumentasi. Sebagian besar data yang tersedia yaitu berbentuk surat, catatan harian, laporan, dan folio. Sifat utama data ini tidak terbatas pada ruang dan waktu sehingga memberi peluang kepada peneliti untuk mengetahui hal-hal yang pernah terjadi diwaktu silam.

\section{HASIL DAN PEMBAHASAN}

Dari hasil uji validitas variabel pengetahuan dapat disimpulkan bahwa 6 item pertanyaan semuanya valid. Dan hasil uji validitas variabel minat dapat disimpulkan bahwa 6 item pertanyaan semuanya valid.

Dari hasil uji reliabilitas menunjukkan bahwa Cronbach's Alpha untuk variabel pengetahuan adalah 0,352 >0,6 sehingga dapat disimpulkan bahwa pada variabel pengetahuan adalah reliabel. Selanjutnya untuk uji reliabilitas variabel minat memilih produk PT Bank Syariah Mandiri menunjukkan bahwa Cronbach's Alpha adalah $0,721>0,6$ sehingga dapat disimpulkan bahwa pada variabel minat demilih produk PT Bank Syariah Mandiri adalah reliabel. Hasil tersebut dapat disimpulkan bahwa variabel-variabel tersebut valid dan semua item peryataan yang di analisis dengan metode Cronbach's Alpha adalah reliabel.

Berdasarkan hasil uji normalitas yang menggunakan uji One Sample Kolmogrov-Smirnov diketahui bahwa nilai signifikan sebesar 0,344 > 0,05. Dapat disimpulkan bahwa data berdistribusi normal. Berdasarkan hasil uji linearitas, nilai Sig sebesar 0,198 jadi dapat disimpulkan nilai Sig. > 0,05 atau 0,198 > 0,05 menunjukkan bahwa hubungan terjadi linearitas. 
Berdasarkan hasil analisis regresi sederhana diperoleh $Y=a+b X$ (Pengetahuan 11,240+0,477 Minat), dengan demikian diketahui bahwa parameter koefisien regresi untuk variabel minat adalah positif terhadap pengetahuan, artinya setiap terjadi peningkatan variabel minat pada pengetahuan, maka pengetahuan juga akan mengalami peningkatan.

Dalam upaya mengidentifikasi seberapa jauh pengaruh variabel pengetahuan terhadapa minat, perlu dilihat dari koefisien determinasinya. Berdasarkan perolehan koefisien determinasi sebesar 0,121 menunjukkan bahwa besarnya variasi variabel minat memilih produk PT Bank Syariah Mandiri Padangsidimpuan dapat dijelaskan oleh variabel minat sebesar $12 \%$ dimana sisanya $88 \%$ dijelaskan oleh faktor-faktor lain diluar penelitian ini.

Berdasarkan hasil analisis dan pengujian hipotesis yang telah dilakukan, maka diperoleh hasil yang menunjukkan bahwa hipotesis alternatif yang menyatakan ada pengaruh antara pengetahuan terhadap minat memilih produk PT Bank Syariah adalah berpengaruh. Hal ini dibuktikan berdasarkan perhitungan uji $t=2,544$. Hasil analisis data menunjukkan bahwa thitung >ttabel $(2,544<$ 2.012), maka hipotesis alternatif berpengaruh. Hasil penelitian ini didukung dengan teori dari Abdul Rahman Saleh dan Muhbib Abdul Wahab dalam bukunya yang berjudul "Psikologi Suatu Pengantar Dalam Perspektif Islam", menyatakan bahwa, "minat adalah kecenderungan untuk memberikan perhatian dan bertindak terhadap orang, aktivitas atau situasi yang menjadi objek dari minat tersebut dengan disertai perasaan senang.

Dan hasil penelitian terdahulu dari skripsi Rohima Harahap dalam penelitiannya menyatakan bahwa,"Hasil penelitiannya ini menunjukkan berdasarkan uji koefisien determinasi dapat diketahui bahwa $68,6 \%$ variavel defenisi, lokasi, prinsip-prinsip dan produk-produk mampu mempengaruhi minat mahasiswa, 31.4\% sisanya dipengaruhi oleh variabel lainnya".

Penelitian terdahulu dari skripsi

Arifatul penelitiannya menyatakan bahwa," variabel pengetahuan masyarakat memiliki pengaruh signifikan terhadap minat menjadi nasabah. Dengan hasil tersebut dikatakan bahwa faktor pengetahuan konsumen mempunyai pengaruh yang dominan untuk minat menjadi nasabah".

\section{PENUTUP}

\section{Kesimpulan}

Berdasarkan hasil penelitian dan pembahasan pengaruh pengetahuan terhadap minat memilih produk PT. Bank Syariah Mandiri Padangsidimpuan (studi kasus pada guru al-azhar bi'ibadillah ujung gading kecamatan batang angkola) dengan melalui penyebaran angket/kuesioner kepada guru Al-Azhar Bi'ibadillah, maka dapat diambil kesimpulan bahwa pengetahuan berpengaruh dan signifikan terhadap minat memilih produk PT Bank Syariah Mandiri Padangsidimpuan.

Hipotesis yang menyatakan pengetahuan berpengaruh terhadap minat memilih produk PT Bank Syariah Mandiri Padangsidimpuan dapat diterima. Presentase sumbangan pengetahuan terhadap minat memilih produk PT Bank Syariah Mandiri Padangsidimpuan sebesar $12 \%$ dan 
selebihnya $88 \%$ dipengaruhi oleh variabel independen lain yang tidak dibahas dalam penelitian ini.

\section{Saran}

Semoga adanya pengetahuan masyarakat terhadap minat produk perbankan syariah

\section{DAFTAR PUSTAKA}

Andi Prastowo, Memahami Metode-metode Penelitian: Suatu Tinjauan Teoritis dan Praktis Jogjakarta: Ar-Ruzz Media, 2014.

Adrianto, Manajemen Bank Syariah Implementasi Teori dan Praktek CV. Penerbit Qiara Media, 2019.

Abdul Rahman Saleh dan Muhbib Abdul Wahab, Psikologi Suatu Pengantar dalam Perspektif Islam Jakarta: Penada Media, 2004.

Amsal Bakhtiar, Filsafat Ilmu Jakarta: PT.Raja Grafindo Persada, 2010.

Arikunto S, Evaluasi Pendidikan Jakarta: Rineka Cipta, 1994.
Ahmad Tafsir, Filsafat Umum Akal dan Hati Sejak Thales Sampai Capra Bandung: PT Remaja Rosdakarya, 2003.

Choirul Mahfud, Pendidikan Multikultural Yogyakarta: Pustaka Pelajar, 2013.

Departemen Pendidikan Nasional, Kamus Besar Indonesia Jakarta: Balai Pustaka, 2005.

Dedy Mulyana, Metode Penelitian Kualitatif Yogyakarta: Pustaka Pelajar, 2006.

Ismail, Perbankan Syariah Jakarta: Prenadamedia Group, 2014.

Kasmir, Manajemen Perbankan Jakarta: Rajawali Pers, 2012.

Muhammad Uzer Usman, Menjadi Guru Profesional Bandung: PT. Remaja Rosdakarya, 2003 cet, ke-25.

Muhammad, Metodologi Penelitian Ekonomi Islam Jakarta: Raja Wali Press, 2009.

Mudrajad Kuncoro, Metode Riset Bisnis dan Ekonomi Jakarta: PT. Raja Grafindo Persada, 2010.

Mardalis, Metode Penelitian Suatu Pendekatan Proposal Jakarta: Bumi Aksara, 2007. 